\title{
Removing the abyss between conservation science and policy decisions in Brazil
}

\author{
Valter M. Azevedo-Santos ${ }^{1} \cdot$ Philip M. Fearnside $^{2} \cdot$
}

Caroline S. Oliveira ${ }^{1}$ - André A. Padial ${ }^{3}$ - Fernando M. Pelicice ${ }^{4}$.

Dilermando P. Lima $\mathrm{Jr}^{5}$ • Daniel Simberloff $\mathrm{f}^{6}$.

Thomas E. Lovejoy ${ }^{7} \cdot$ André L. B. Magalhães $^{8}$ •

Mario L. Orsi ${ }^{9}$ - Angelo A. Agostinho ${ }^{10}$ - Francisco A. Esteves ${ }^{11}$.

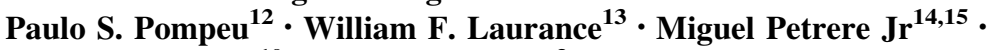

Roger P. Mormul ${ }^{10}$ • Jean R. S. Vitule ${ }^{3}$

Received: 8 December 2016/Revised: 4 February 2017/ Accepted: 9 February 2017 /

Published online: 16 February 2017

(C) Springer Science+Business Media Dordrecht 2017

\begin{abstract}
The executive and legislative branches of Brazilian government have either proposed or taken a variety of initiatives that threaten biodiversity and ecosystems. Opposition by the scientific community has largely been ignored by decision-makers. In this short essay, we present recent examples of harmful policies that have great potential to erode biodiversity, and we suggest ways to communicate scientific knowledge to decision-
\end{abstract}

Communicated by David Hawksworth.

Valter M. Azevedo-Santos

valter.ecologia@gmail.com

1 Laboratório de Ictiologia, Departamento de Zoologia, Universidade Estadual Paulista "Júlio de Mesquita Filho", Botucatu, SP 18618-970, Brazil

2 Instituto Nacional de Pesquisas da Amazônia (INPA), Manaus, AM 69067-375, Brazil

3 Pós-Graduação em Ecologia e Conservação; Laboratório de Ecologia e Conservação, Departamento de Engenharia Ambiental; Laboratório de Análise e Síntese em BiodiversidadeDepartamento de Botânica, Universidade Federal do Paraná, Curitiba, PR, Brazil

4 Núcleo de Estudos Ambientais, Universidade Federal de Tocantins, Porto Nacional, TO 77500-000, Brazil

5 Laboratório de Ecologia e Conservação de Ecossistemas Aquáticos, Universidade Federal do Mato Grosso, Campus Universitário do Araguaia, Pontal Do Araguaia, MT 78698-000, Brazil

6 Department of Ecology and Evolutionary Biology, University of Tennessee, Knoxville, TN 37996, USA

7 Department of Environmental Science and Policy, George Mason University, Fairfax, VA 22030, USA

8 Programa de Pós-Graduação em Tecnologias para o Desenvolvimento Sustentável, Universidade Federal de São João Del Rei, Ouro Branco, MG 36420-000, Brazil

9 Departamento de Biologia Animal e Vegetal, Universidade Estadual de Londrina, Londrina, PR 86057-970, Brazil 
makers. If the current gap between conservation science and policies is not filled, the country will threaten the maintenance of its natural capital and, consequently, the sustainability of essential societal activities in the long term.

Keywords Environmental laws - Scientific advice · Forest Code · Biodiversity, Translational scientists, Environmental impacts, Neotropical biodiversity

\section{Introduction}

Brazil has a prominent place in maintaining global biodiversity. The country has continental dimensions, covers tropical and sub-tropical latitudes, and contains a huge diversity of biomes, ecosystems, and species (Lewinsohn and Prado 2005; Silva 2005), many of which are still poorly known or critically endangered (MMA 2014; IUCN 2015; Vitule et al. 2016). Efforts to conserve biodiversity have increased in recent years: for instance, the "Plan of Action for Prevention and Control of Deforestation in the Legal Amazon" (PPCDAm) launched in 2004 (MMA 2013), a shift in 2007 in Brazil's position in climate negotiations to allow compensation for avoiding deforestation (Fearnside 2012), creation of protected areas (Soares-Filho et al. 2010) and improvements in systems for satellite monitoring of deforestation in near real time beginning in 2006 (Assunção et al. 2013). However, much greater effort is needed to effectively stem unsustainable environmental policies (Loyola 2014; Lima-Junior et al. 2015). Virtually all major biomes and ecosystems have been significantly impacted by human activities; some have been extensively transformed or destroyed (e.g. Atlantic rainforest, Paraná River Basin). In recent years, unsustainable policies have stimulated a series of harmful initiatives, with great potential to damage biodiversity and ecosystem functioning because they consistently ignore scientific consensus and advice. This scenario adds urgency to the need to connect decision-makers with scientific knowledge in both the executive and legislative branches of government.

In this short essay, we provide a brief overview of recent unsustainable policies and stress the need to connect environmental science with policy decisions as an unavoidable step to preserve Neotropical biodiversity and its services. We hope researchers in other nations in which science is also far from decision-making will propose similar initiatives.

10 Programa de Pós-Graduação em Ecologia de Ambientes Aquáticos Continentais (PEA), Universidade Estadual de Maringá, Maringá, PR 87020-900, Brazil

11 Núcleo em Ecologia e Desenvolvimento Sócio Ambiental de Macaé, Universidade Federal do Rio de Janeiro, Macaé, RJ 27965-045, Brazil

12 Laboratório de Ecologia de PeixesSetor de Ecologia, Departamento de Biologia, Universidade Federal de Lavras - UFLA, Campus Universitário, Lavras, MG 37200- 000, Brazil

13 Centre for Tropical Environmental and Sustainability Science (TESS) and College of Marine and Environmental Sciences, James Cook University, Cairns, QLD 4878, Australia

14 Programa de Pós-Graduação em Planejamento e Uso de Recursos Renováveis, Universidade Federal de São Carlos, Sorocaba, SP 18052-780, Brazil

15 Programa de Pós-Graduação em Sustentabilidade de Ecossistemas Costeiros e Marinhos, UNISANTA, Santos, SP, Brazil 


\section{Unsustainable policies}

A variety of proposed laws (Projetos de Lei-PL, in Portuguese), constitutional amendments (Proposta de Emenda à Constituição-PEC, in Portuguese), and provisional measures (Medida Provisória-MP, in Portuguese) have surfaced in recent years (see Pelicice et al. 2014; Fearnside 2016a; Magalhães et al. 2017; Ruaro and Mormul 2017). We offer some examples of harmful initiatives under consideration or approved in Brazil today.

Proposed federal law No. 5989/09, which designates non-native fishes as "naturalized," will enhance the use of non-native species in Brazilian aquaculture (Azevedo-Santos et al. 2011; Pelicice et al. 2014). The scientific community has criticized the proposal (e.g. Azevedo-Santos et al. 2011; Lima-Junior et al. 2012; Vitule et al. 2012; Pelicice et al. 2014), but it continues to progress through the federal legislature and will likely became a reality. Similarly, a state law (No. 4330/2016) was recently sanctioned allowing aquaculture with non-native fish (e.g. Nile tilapia Oreochromis niloticus) in Amazonas state (Tófoli et al. 2016; Padial et al. 2017). Both laws can boost fish invasions across Brazil (Pelicice et al. 2014), posing significant threats to the natural environment (e.g. Vitule et al. 2009) and possibly causing important socioeconomic consequences (e.g. Pimentel et al. 2005) in biomes of global interest.

Other threats include a variety of assaults on the environmental licensing system. PEC 65 , for example, would effectively eliminate licensing by automatically approving projects with the mere submission of an environmental impact study; this proposal is close to a final vote in the Senate plenary. This case is similar to another proposed law (PLS 654/2015) that would greatly abbreviate the licensing process for major infrastructure projects (Fearnside 2016a). In the House of Deputies, a similar proposed law (PL 3729/2004) was recently promoted to "urgent" status and is progressing towards a vote (Fearnside 2016b). Another law (MPV 727, renamed PL de conversão 23/2016) was approved in September 2016, with clauses similar to the proposed laws that abbreviate licensing. All these proposals will have enormous negative impacts on biodiversity (Fearnside 2016a, b), as largescale development projects will grant approval regardless of their environmental costs.

Finally, attempts to weaken the Brazilian System of Conservation Units are frequent (Bernard et al. 2014). Although processing of the proposal (PL 3682/2012) that "calls for $10 \%$ of even strictly protected areas to open for mining concessions, and general prohibition of new PAs in areas of high mineral or hydropower potential" (Ferreira et al. 2014, p. 706) has been suspended, decreases in some protected areas continue to be implemented through provisional measures (e.g. ISA 2016). In a context in which several scientists have warned about the importance of protected areas (e.g. Scarano et al. 2012), decreasing them is a substantial setback.

\section{A bridge between science and policy decisions}

Brazilian environmental policy has been weak because environmental issues have little influence on government. Surely, the limitation on participation of the scientific community at all political levels (federal, state, and municipal) is a major impediment to policies being formulated based on high-quality information. In Brazil, communication between scientists and policy-makers is historically deficient: while decision-makers do not consult scientists, scientists do not act efficiently to be heard. Some suggestions to try to bridge the gap between conservation scientists and decision makers are presented in Fig. 1. 


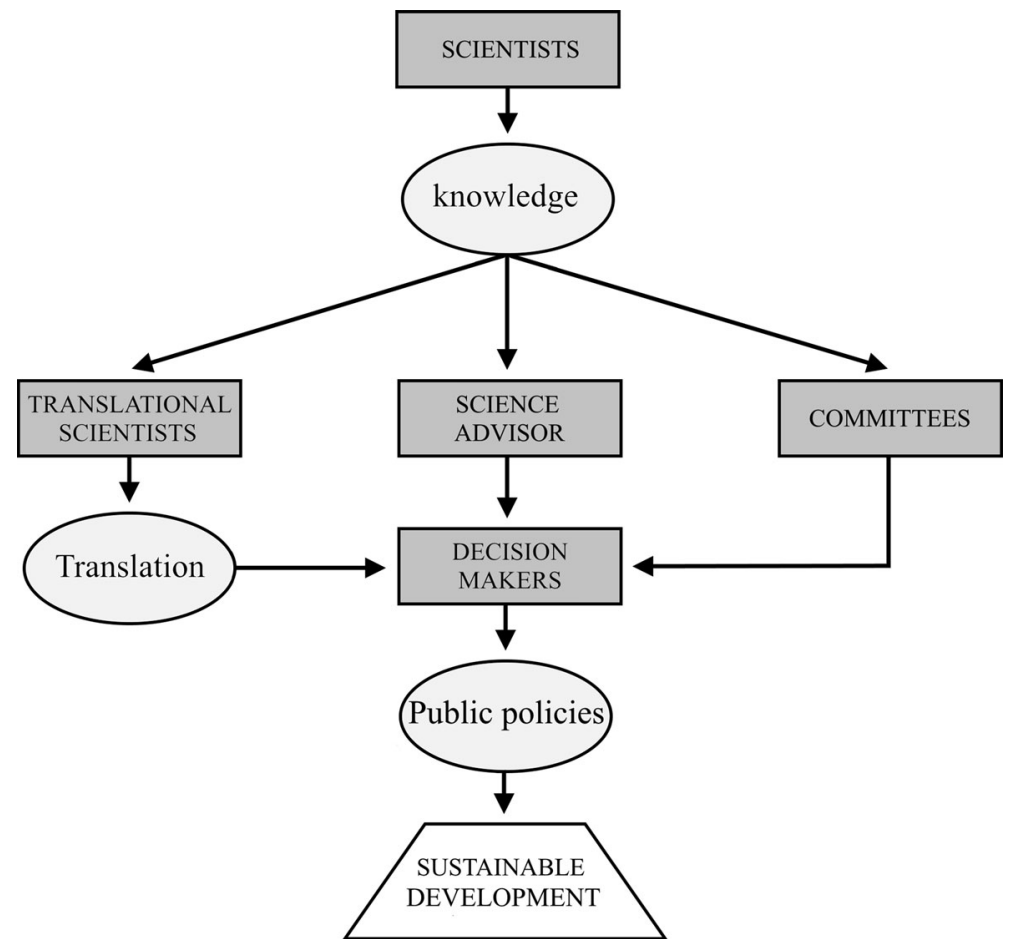

Fig. 1 Paths to improve the connection between scientific knowledge and decision-makers, with the objective to propose sustainable policies

\section{Executive level}

Many countries have a science advisor at the executive level, although there is variation in the degree to which these advisors affect policy. A well-known example of executive decisions without scientific input was US President George W. Bush's unilateral decision to withdraw the United States from the Kyoto Protocol in March 2001, before he had appointed a science advisor. In Brazil a clear example is the construction of the Belo Monte Dam in the Amazon Basin; this expensive megaproject was much criticized by the scientific community, including a specialist panel (see Santos and Hernandez 2009) that was ignored by the Brazilian government. This is not an exception, because formal technical opinions (pareceres, in Portuguese) by technical staff have been overridden by high-level political decisions in other cases, such as the environmental licensing of the Santo Antônio, Jirau, and Belo Monte hydroelectric dams (Fearnside 2014, 2017). Brazil has no presidential science advisor despite the existence of scientific committees in various ministries, e.g., the Ministry of Science, Technology, Innovation and Communication and the Ministry of the Environment. We emphasize that these ministries include strong scientific staff, i.e. professors and scientists working at different research institutes and universities. Decision-makers can consult these committees and specialists when advice is desired, but they may also choose to ignore them. 


\section{Legislative level}

The existing committee system is the logical conduit for scientific input to the legislative process. Brazil's House of Deputies has a committee whose purview includes science (CCTCI = Comissão de Ciência e Tecnologia, Comunicação e Informática) and another committee for the environment and sustainable development (CMADS = Comissão de Meio Ambiente e Desenvolvimento Sustentável). The Federal Senate also has committees for these two areas (CCT = Comissão de Ciência e Tecnologia and CMA = Comissão de Meio Ambiente). Elected politicians constitute these committees, and in principle, they must consult specialists to make decisions. The effectiveness of these committees, however, is dubious. An example is provided by the 2011-2012 debates over reforming (gutting) the country's "Forest Code", which is a package of regulations that governs deforestation (e.g. Metzger et al. 2010; Nazareno et al. 2012; Soares-Filho et al. 2014; Brancalion et al. 2016). The law that was approved in 2012 (Law No. 12,651/2012), for example, reduced protection requirements on private properties and pardoned 43 years of violations of the previous "Forest Code". Various scientists questioned the reform in committee hearings, and ample literature was provided by the Brazilian Society for the Progress of Science (SBPC) and the Brazilian Academy of Science (ABC) (e.g. Silva et al. 2011). This input, however, had no effect on the vote, which mostly followed political parties' guidelines; the House of Deputies passed the reform by a margin of seven to one (see Fearnside 2016a). It should be mentioned that the Brazilian Enterprise for Agricultural and Ranching Research (EMBRAPA), which is the main scientific arm of the Ministry of Agriculture, explicitly prohibited its researchers from expressing any opinions on the proposed revision of the "Forest Code" when the revision was being debated in the National Congress (Angelo 2011).

Turnout in committee hearings is often low unless a high-profile topic is on the agenda, as occurred during the recent presidential impeachment case. The poor turnout is evident when sessions are focused on acquiring information rather than producing a vote, yet gaining information is a crucial step in guiding legislators toward wise decisions. Therefore, a mechanism is needed to force authorities to give serious and regular consideration to scientific advice. Of course, scientists cannot wield a veto over decisions of elected officials. Nevertheless, researchers are armed with high-quality information that may influence elected officials. One suggestion is to develop a mechanism that demands testimony from relevant scientists indicated by credible organizations such as SBPC, ABC and ABECO (Brazilian Association for Ecological Science and Conservation). In addition, to have an effect, a minimum level of participation by committee members must be assured, for example by a required minimum quorum (as in the case of sessions for voting). Actual presence is essential, not simply signing an attendance sheet and leaving (as often occurs). The relation between legislative sovereignty and the need to incorporate scientific concerns therefore entails a delicate balance.

\section{Translational scientists}

Equally important is improving capacity for "translational scientists" (see Brosnan and Groom 2006 for more details), who are still somewhat unusual among conservation scientists in Brazil. Modern science is loaded with concepts, methods, and theories that are impenetrable to non-specialists. This bulk of information is difficult to grasp if proper assistance is limited. To bridge this gap, translational scientists would catalyze 
understanding of research on conservation issues (Brosnan and Groom 2006; Briske 2012) and guide authorities, managers, and policy-makers through complicated topics and intricate data, especially in areas where deficient data and conflicting results are common. This may be a significant way to implement science-based decisions, because "translations" may reach authorities as well as the lay public, which exerts pressure on policymakers.

\section{Final remarks}

In Brazil (and elsewhere), environmental policy decisions should not be isolated by political agents, especially because these decisions are often based on poor-quality information. Misguided measures can promote unsustainable activities and drastically erode biodiversity, with long-term effects on the maintenance of essential ecosystem services and economic activities. Some decisions obviously transcend scientific ignorance and are offered only in order to promote lobbies or to finance new political campaigns; e.g., recent confessions released by federal courts indicate that corruption led to approval and construction of the Belo Monte Dam (Megale et al. 2016). Involvement of scientists, as we propose, could at least hinder approval of projects with harmful consequences to biodiversity, resources, and natural capital.

Although more data and high-quality research are needed, these will not suffice to improve biodiversity conservation (Ellison 2016). Many Brazilian and foreign scientists are producing scientific data on biodiversity and conservation in Brazil, but the knowledge abyss persists between science and decision-making. If this gap is not filled, maintenance of the country's natural capital will be threatened and, consequently, the sustainability of essential societal activities.

Acknowledgements We are grateful to Ricardo C. Benine and Paula N. Coelho for comments and suggestions in the first version of this work. VMAS, CSO and ALBM were supported by Coordenação de Aperfeiçoamento de Pessoal de Nível Superior (CAPES); PMF, FMP, PSP, AAP, AAA and JRSV were supported by Conselho Nacional de Desenvolvimento Científico e Tecnológico (CNPq).

\section{References}

Angelo C (2011) Embrapa veta cientistas em seminário. Folha de São Paulo 25 February 2011. http://www1. folha.uol.com.br/fsp/ciencia/fe2502201102.htm (in Portuguese) Accessed 28 January 2017

Assunção J, Gandour C, Rocha, R (2013) DETERing deforestation in the Amazon: Environmental monitoring and law enforcement. Climate Policy Initiative, Núcleo de Avaliação de Políticas Climáticas, Pontifica Universidade Católica (PUC), Rio de Janeiro, pp. 36 http://climatepolicyinitiative.org/wpcontent/uploads/2013/05/DETERring-Deforestation-in-the-Brazilian-Amazon-EnvironmentalMonitoring-and-Law-Enforcement-Technical-Paper.pdf. Assessed 1 Feb 2017

Azevedo-Santos VM, Rigolin-Sá O, Pelicice FM (2011) Growing, losing or introducing? Cage aquaculture as a vector for the introduction of non-native fish in Furnas Reservoir, Minas Gerais, Brazil. Neotrop Ichthyol 9:915-919. doi:10.1590/S1679-62252011000400024

Bernard E, Penna LAO, Araújo E (2014) Downgrading, downsizing, degazettement, and reclassification of protected areas in Brazil. Conserv Biol 28:939-950. doi:10.1111/cobi.12298

Brancalion PHS, Garcia LC, Loyola R et al (2016) A critical analysis of the Native Vegetation Protection Law of Brazil (2012): updates and ongoing initiatives. Nat Conserv 14S:1-15. doi:10.1016/j.ncon. 2016.03.003

Briske DD (2012) Translational science partnerships: key to environmental stewardship. Bioscience 62:449-450. doi:10.1525/bio.2012.62.5.2 
Brosnan DM, Groom MJ (2006) The integration of conservation science and policy. Pp. 625-659. In: Groom MJ, Meffe GK, Carrol RC (eds) Principles of Conservation biology, 3rd edn. Sinauer Associates, Sunderland, p 793

Ellison AM (2016) It's time to get real about conservation. Nature 538:141. doi:10.1038/538141a

Fearnside PM (2012) Brazil's Amazon forest in mitigating global warming: unresolved controversies. Clim Policy 12(1):70-81. doi:10.1080/14693062.2011.581571

Fearnside PM (2014) Brazil's Madeira River dams: A setback for environmental policy in Amazonian development. Water Altern 7(1): 156-169. http://www.water-alternatives.org/index.php/alldoc/ articles/vol7/v7issue1/244-a7-1-15/file

Fearnside PM (2016a) Brazilian politics threaten environmental policies. Science 353:746-748. doi:10. 1126/science.aag0254

Fearnside PM (2016b) Political back-room deals imperil the Brazilian Amazon. Alert 3 September 2016. http://alert-conservation.org/issues-research-highlights/2016/9/2/political-back-room-deals-imperil-thebrazilian-amazon

Fearnside PM (2017) Belo Monte: Actors and arguments in the struggle over Brazil's most controversial Amazonian dam. Die Erde (in press)

Ferreira J, Aragão LEOC, Barlow J et al (2014) Brazil's environmental leadership at risk. Science 346:706-707. doi:10.1126/science.1260194

ISA (Instituto Socioambiental) (2016) Governo Temer altera unidades de conservação e fragiliza proteção à floresta no Pará. Notícias Socioambientais, 21 December 2016. https://www.socioambiental.org/pt-br/ noticias-socioambientais/governo-temer-altera-unidades-de-conservacao-e-fragiliza-protecao-a-florestano-para. Assessed 2 Feb 2017

IUCN (2015) The IUCN Red List of Threatened Species. Version 2015-4. http://www.iucnredlist.org. Accessed 23 Nov 2015

Lewinsohn TM, Prado PI (2005) How many species are there in Brazil? Conserv Biol 19:619-624. doi:10. 1111/j.1523-1739.2005.00680.x

Lima-Junior DP, Pelicice FM, Vitule JRS, Agostinho AA (2012) Aquicultura, política e meio ambiente no Brasil: novas propostas e velhos equívocos. Nat Conserv 10:88-91. doi:10.4322/natcon.2012.015

Lima-Junior DP, Magalhães ALB, Vitule JRS (2015) Dams, politics and drought threat: the March of folly in Brazilian freshwaters ecosystems. Nat Conserv 13:196-198. doi:10.1016/j.ncon.2015.11.003

Loyola R (2014) Brazil cannot risk its environmental leadership. Divers Distrib 20:1365-1367. doi:10.1111/ ddi.12252

Magalhães ALB, Santos VMR, Lima-Junior DP et al (2017) Brazil austerity plans threaten biodiversity. Nature 542:295. doi:10.1038/542295e

Megale B, Rocha G, Cruz V, Colon L (2016) Propina abasteceu campanha de Dilma de 2014, diz Andrade Gutierrez. Folha de São Paulo 7 April 2016. http://www1.folha.uol.com.br/poder/2016/04/1758307propina-abasteceu-campanha-de-dilma-de-2014-diz-andrade-gutierrez.shtml (in Portuguese) Accessed 28 January 2017

Metzger JP, Lewinsohn TM, Joly CA et al (2010) Brazilian law: full speed in reverse? Science 329:276-277. doi:10.1126/science.329.5989.276-b

MMA (Ministério do Meio Ambiente). (2013) Plano de Ação para Prevenção e Controle do Desmatamento na Amazônia Legal-PPCDAm $3^{\text {a }}$ Fase (2012-2015). MMA, Brasília, pp. 171 http://www.mma.gov.br/ images/publicacoes/florestas/Catalogo/Tema3_Prevencao-Controle-Desmatamento/PPCDAm_3afase.pdf. Assessed 1 February 2017

MMA (Ministério do Meio Ambiente) (2014) Portaria no 443 e 444, de 17 de dezembro de 2014. MMA, Brasília

Nazareno AG, Feres JM, Carvalho D et al (2012) Serious new threat to Brazilian forests. Conserv Biol 26:5-6. doi:10.1111/j.1523-1739.2011.01798.x

Padial AA, Agostinho AA, Azevedo-Santos VM et al (2017) The "Tilapia Law" encouraging non-native fish threatens Amazonian River basins. Biodivers Conserv 26:243-246. doi:10.1007/s10531-016-12290

Pelicice FM, Vitule JRS, Lima-Junior DP, Orsi ML, Agostinho AA (2014) A serious new threat to Brazilian freshwater ecosystems: the naturalization of non- native fish by decree. Conserv Lett 7:55-60. doi:10. 1111/conl.12029

Pimentel D, Zuniga R, Morrison D (2005) Update on the environmental and economic costs associated with alien-invasive species in the United States. Ecol Econ 52:273-288. doi:10.1016/j.ecolecon.2004.10. 002

Ruaro R, Mormul RP (2017) Anticipated changes to environmental law may jeopardize Brazilian natural resources. Front Ecol Environ (in press) 
Santos SMSBM, Hernandez FM (2009) Painel de especialistas. Análise Crítica do Estudo de Impacto Ambiental do Aproveitamento Hidrelétrico de Belo Monte. Available at: https://www.socioambiental. org/banco_imagens/pdfs/Belo_Monte_Painel_especialistas_EIA.pdf

Scarano F, Guimarães A, Silva JM (2012) Lead by example. Nature 486:25-26. doi:10.1038/486025a

Silva M (2005) The Brazilian protected areas program. Conserv Biol 19:608-611. doi:10.1111/j.1523-1739. 2005.00707.x

Silva JAA, Nobre AD, Manzatto CV et al. (2011) O Código Florestal e a Ciência: Contribuições para o Diálogo. Sociedade Brasileira para o Progresso da Ciência (SBPC), São Paulo, SP \& Academia Brasileira de Ciências (ABC), Rio de Janeiro, pp. 124. Available at: http://www.abc.org.br/IMG/pdf/ doc-547.pdf (2011)

Soares-Filho BS, Moutinho P, Nepstad D et al (2010) Role of Brazilian Amazon protected areas in climate change mitigation. Proc Natl Acad Sci USA 107(24):10821-10826. doi:10.1073/pnas.0913048107

Soares-Filho B, Rajão R, Macedo M et al (2014) Cracking Brazil's forest code. Science 344:363-364. doi:10.1126/science. 1246663

Tófoli RM, Alves GHZ, Dias RM, Gomes LC (2016) Brazil's Amazonian fish at risk by decree. Science 353:229. doi:10.1126/science.aag2922

Vitule JRS, Freire CA, Simberloff D (2009) Introduction of non-native freshwater fish can certainly be bad. Fish Fish 10:98-108. doi:10.1111/j.1467-2979.2008.00312.x

Vitule JRS, Lima-Junior DP, Pelicice FM, Orsi M, Agostinho AA (2012) Ecology: preserve Brazil's aquatic biodiversity. Nature 485:309. doi:10.1038/485309c

Vitule JRS, Agostinho AA, Azevedo-Santos VM et al (2016) We need better understanding about functional diversity and vulnerability of tropical freshwater fishes. Biodivers Conserv 26:757-762. doi:10.1007/ s10531-016-1258-8 